\title{
The Roles of Information and Communication Technologies (ICTs) and E-Commerce as Agents of Nigeria's Economic Development: Review of Challenges and Prospects
}

\author{
Bitrus Joseph \\ Department of Computer Science, Federal University Wukari, Wukari, Nigeria \\ Email: bitrusjoseph1@gmail.com
}

How to cite this paper: Joseph, B. (2019) The Roles of Information and Communication Technologies (ICTs) and E-Commerce as Agents of Nigeria's Economic Development: Review of Challenges and Prospects. Wireless Engineering and Technology, 10, 41-54.

https://doi.org/10.4236/wet.2019.103004

Received: June 25, 2019

Accepted: July 28, 2019

Published: July 31, 2019

Copyright $\odot 2019$ by author(s) and Scientific Research Publishing Inc. This work is licensed under the Creative Commons Attribution International License (CC BY 4.0).

http://creativecommons.org/licenses/by/4.0/

\begin{abstract}
Electronic commerce which denotes the process of electronic transaction via internet has led to a very significant improvement in the level of growth, development, efficiency and productivity of global economies. In order to benefit from the economic opportunities offered by electronic commerce, Nigerian government and business organizations needs to effectively integrate Information and Communication Technologies (ICTs) as the major component of e-commerce campaign initiatives. The discussion in the paper is centered on e-commerce and ICTs and their resultant effect on Nigeria's economic growth and development. This paper has presented an in-depth discussion of the various types of e-commerce, the major contributions of e-commerce to the economic growth of Nigeria and finally the challenges that impede the growth of e-commerce in Nigeria were identified and the possible recommendations for solutions to those challenges were provided.
\end{abstract}

\section{Keywords}

Business Transaction, E-Commerce, Global Economy, ICT, Internet, Nigeria

\section{Introduction}

The invention of computers gave birth to Information and Communication Technology (ICT) which in turn has immensely altered the mode of human interaction by providing portable and faster means of communication in recent times. The applications of ICT in business transactions today have changed the world into a global marketplace via the use of e-commerce technologies [1]. The 
rapid increase in the growth and applications of ICT in businesses today have caused a lot of enterprises in Nigeria to adopt e-commerce in their business operations so as to meet their customers' urgent need for modern technologies and innovations [2]. Previous studies by [3] disclosed that Nigeria has experienced considerable level of progress and development in the ICT sector within the first decade of the $21^{\text {st }}$ century; this is mainly due to the large number of ICT-related infrastructural development recorded in the country between the years 2000 and 2009. Despite the perceived level of progress in Nigeria's ICT sector, Nigeria is still lagging behind in terms of digital development when compared to its competing economy emerging countries of the world. In another study [4] emphasized that Information and communication technologies (ICTs) proved to be one of the factors that necessitated the speedy growth of e-Commerce transactions in today's global economy; it has influenced organizations, businesses and purchasers otherwise known as e-consumers positively in our society. Electronic commerce or e-Commerce is highly favored due to its global market accessibility as well as its compatible application in all types of businesses. The increasing global rate of online business transactions with the associated innovative attitude of the customers has forced organizations to adopt e-Commerce to become a vital component of their businesses.

Various researchers have shown that the history of electronic commerce dates back to the late twentieth century. According to [5] e-commerce was successfully employed for selling and buying products online for the first time in the year 1994, with the on-line sale of Ten Summoner's Tales, Sting's fourth album. After a period of twenty years from the time, it was first introduced, e-commerce has spread all over the world, and it has an estimated global value of $\$ 1500$ billion in the year 2014. Despite all the contributions of e-commerce to the global economic development, the Middle East and African regions were reported to be in the marginal position of e-commerce development compared to other regions of the world. Previous studies by [6] defined e-commerce as the exchange of goods and services, usually conducted over computer networks by different methods and processes that were designed purposely for placing and accepting orders from customers. The products and services must be ordered online by those methods, but the options for payment and delivery of the goods and services are not necessarily conducted online. [7] in their research defines e-commerce as the buying and selling of goods and services over the Internet; based on their research, those who engage in the transaction of buying and selling of goods and services over the Internet are called "electronic consumers" or e-consumers for short. In another related research [1] argued that e-commerce encompasses the collections of online business transactions which has to do with the exchange of products and services between producers and consumers of such products and services mainly over Internet. It also involves the sharing of business information electronically and the digital processing of such business information by using the modern technology in order to enhance the satisfaction of both parties involved in the transaction; in e-commerce, the parties involved in the business 
transaction interact electronically in a virtual market place rather than by direct physical contact.

The use of Internet to conduct online business transactions today has now been established as a strong marketing strategy that drives e-commerce which has been recognized worldwide as a mechanism that empower business organization to compete in the global markets based on the facts that marketers use the Internet to gather data for marketing survey and planning [8]. Similarly previous study by [9] exposed that Nigeria has the highest rate of Internet connectivity in Africa, recording over 56 million Internet users in the year 2013. This high rate of Internet penetration in Nigeria has motivated a reasonable number of business organizations to compete with other businesses from different regions of the world within the virtual market place and the online business environment with much support from the over 56 million Internet subscribers in the country.

\section{Literature Review}

The e-commerce remains the most prominent application of information technology (IT) that has revolutionized the global economies in recent years; it is clearly associated with all the processes that directly or indirectly involves the buying, selling and exchange of goods and services by means of computer networks and the Internet [9]. Electronic commerce has found much application in the banking industry most especially in the area of e-banking in recent times. Another study by [10] disclosed that e-banking denote the process of carrying out banking transactions such as payment of bills, fund transfer and withdrawal of cash using Automated Teller Machine (ATM) as some of the prominent contribution of e-commerce in the global economy most especially in Nigeria. In line with the disclosure made above, [11] emphasized that e-banking encompasses the different types of banking operations, transactions and activities conducted over the Internet through the help of electronic network of computers; it stands as the major delivery platform of all the banking services that is widely applied in both the Business-to Business and Business-to-Consumer e-commerce transactions in recent times.

The results of a research conducted by [12] suggested that bankers in Nigeria regard electronic banking as a necessary mechanism that helps to reduce the level of inconveniences encountered during banking transactions; it also minimizes transaction costs as well as enhancing customers banking experience by reducing the amount of time needed for customers to carry out transaction in Nigerian banks. Electronic banking was also reported by [13] as another opportunity for economic growth and development offered by the adoption of e-commerce in the banking industry in Nigeria; because the quality of financial service delivery in Nigerian banking sector was very poor before the introduction of electronic banking in the country in the 1990s which was primarily driven by the new generation. This was a deliberate attempt to address the challenges associated with the manual processing of transactions that forced customers to spend many 
hours queuing up in the banking hall before they can carry out transactions either to deposit money into their accounts, withdraw money from their accounts or pay their bills.

According to [14] improvement in information and communication technologies and Internet services have completely changed the way and manner of conducting business transactions through the introduction of new and smatter ways of conducting business operations known as online shopping. The concept of online shopping is another aspect of e-commerce that has experienced a rapid growth in Nigeria recently; it is simply the type of shopping in which consumers visit an online store, portal or website solely to order for or buy a product online. [15] in their studies posited that the adoption, practice and proper utilization of e-commerce and Internet in businesses can led to an appreciated level of economic growth and development, one notable feature of the Internet is its vast ability of bringing different people from different parts of the world together into a global electronic market place known with other names such as online stores or virtual market place. The timely delivery and processing of consumers' order for products from an online store is considered to have a positive influence on the economies of developing countries like Nigeria. [16] In his research opined that Internet and the World Wide Web (WWW) or web for short are the two products of technological innovations that propelled many organizations to conduct transactions, exchange information, and to work jointly with others across the different geographical territories of the world and across computing platforms that are connected in a network of computers. The Internet and its accompanying technology is a vital tool that ensures continuity, growth and success of businesses in today's competitive business environment. The importance of e-commerce cannot be overemphasized because it has affected the ways and manners through which business transactions were carried out today. Recent studies by [17] revealed that after many years of investigation on electronic commerce, it was found to have affected virtually every business in a positive way for example, the online booksellers and music stores and other online businesses like Amazon, Barnes and Noble, Borders, and e-Bay just to mention few were connected to a significant consumer segment due to their online presence in an e-commerce market place.

\section{Types of E-Commerce}

There are four major types of e-commerce to be discussed in this paper and all its associated e-commerce models were adapted from [18]. The following are the four types of e-commerce discussed in this paper:

1) Business-to-Business (B2B): this type of e-commerce has to do with the use of Internet to bring about modern supply-chain operations such as electronic data interchange and electronic funds transfer between two or more business organizations; it also involves companies that engage on a business deal with each other such as producers and manufacturers selling to distributors, and 
wholesalers selling in bulk to unit retailers [19] [20]. The Business to Business model of e-commerce is shown in Figure 1 below.

2) Business-to-Consumer (B2C): this type of e-Commerce involves a transactions between a business organization and its target consumer thereby creating an electronic medium that allows instant transfer of messages and information, it also enables the sharing of goods and services between business organizations and final consumers in a retailing transaction; it can be regarded as an e-commerce model that involves the selling and buying of goods and services between businesses and consumers over the Internet. It also involves direct selling of products from businesses to their substantive consumers [21] [22]. A typical example of Business-to-Consumer e-commerce model in Nigeria is Jumia. The Business to Consumer model of e-commerce is shown in Figure 2 below.

3) Consumer-to-Business (C2B): this model of e-commerce is characterized by consumers of products and services advertising online what price they are ready to pay for a given service, product or loan while the business organizations involved in such business responds accordingly; this type of e-commerce enables both business owners and consumers of products and services to have a neutral meeting ground where prices of goods and services are negotiated and also the provision of platforms for such commercial transactions to take place [20] [23]. The Consumer to Business model of e-commerce is shown in Figure 3 below.

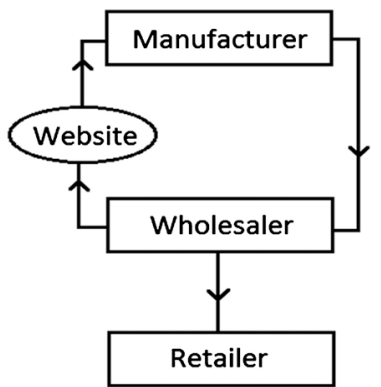

Figure 1. The e-commerce Business to Business model (Source: [18]).

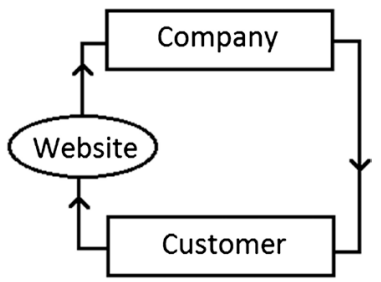

Figure 2. The e-commerce Business to Consumer model (Source: [18]).

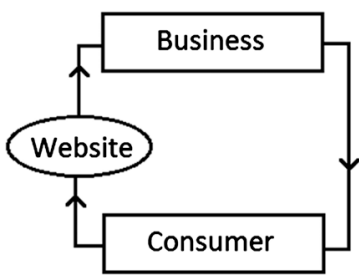

Figure 3. The e-commerce Consumer to Business model (Source: [18]). 


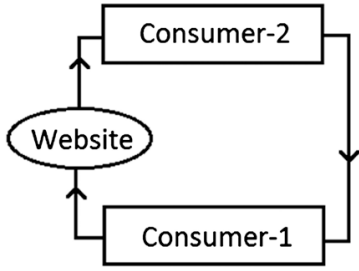

Figure 4. The e-commerce Consumer to Consumer model (Source: [18]).

4) Consumer-to-Consumer (C2C): this refers to the type of e-commerce in which consumers interact and carry out a direct business transaction with other consumers in a virtual market place known as cyberspace [24]. The Consumer to Consumer model of e-commerce is shown in Figure 4.

\section{Contributions of e-Commerce in Nigeria's Economic Growth}

The inclusion and adoption of ICT services and Internet Technology for e-commerce in business organizations in Nigeria presents the following as major contributions of e-commerce to Nigeria's economic growth and development:

1) Improvement in the current channels of payment in the Nigeria's

\section{Banking industry}

The Nigerian Banking sector has shown a remarkable level of improvement in the quality of their service delivery most especially in terms of making payments to customers today. The e-commerce technology has brought about the emergence of various E-Payment systems which make use of other alternatives to cash like debit cards, credit cards, electronic funds transfer, Internet banking and e-payment systems. Presently, buyers and sellers can pay and receive money from other means apart from raw cash; such monetary payments can be achieved using e-payment systems, the Automated Teller Machine (ATM), Internet or online transaction, Point of Sale terminals (POS), Mobile money solutions are good examples of the e-payment systems that have helped to improve the quality of payments in the Nigerian banking sector [25].

2) Serves as a link that Connects Customers, Workers, Suppliers, Distributors and Competitors in a Business Environment

Previous study by [26] stressed that the adoption of e-Commerce helps in networking the various business organizations together there by enabling small business organizations to depend on other business organizations otherwise known as "partners" for supplies, product distribution and to meet customer demands for products and services more effectively through the implementation of a very functional e-commerce supply chain management solution.

\section{3) Facilitates 24/7 Operation of Businesses}

Business organizations that adopt E-commerce in their business set up can sell their products either in the night or during the day time, business transactions can be carried out for 365 days a year. Even while business owners have closed for the day to rest, their potential customers can visit the business online store or 
web site to search for goods and services and to place their orders [22] [27].

\section{4) Promotes the Development of Local Online stores in Nigeria}

Many Nigerian companies and business ventures were engaged in active global market competition through the development of universal business portals and online stores which they used to advertise their products and services to their target consumers and buyers [28]. Typical examples of indigenous Nigerian business organizations that have achieved a remarkable success in online business transactions include Jumia, Konga and Jiji; these Nigerian owned business ventures were engaged in active global economic competition through their universal accessibility and online presence.

\section{5) Creation of jobs and Employment opportunities}

According to [29] in their study on "Roles of E-Service in Nigeria's Economic Development" The creation of jobs through ICT driven platforms which is the backbone of e-commerce in Nigeria has experienced a significant improvement whose Capacity building in recent times has generated huge revenue for the government each year.

6) Helps in the Removal of Fraudulent Payees from the Government Payroll.

Reports by e-Transform Africa in the year 2012 on ICT Competitiveness reveals that in the year 2008, the Federal government of Nigerian in collaboration with the World Bank had successfully implemented an Integrated Personnel and Payroll Information System (IPPIS) which was aimed at reducing fraud and increasing the level of accountability in payroll administration and human resource management records in the country. It was reported that an estimated 12 billion naira (US\$120 Million) were saved by the technological implementation solely in the pilot phase; this is achieved through the elimination of "ghost workers or fraudulent payees on the payroll" [30]. It can be seen that the adoption of modern technology like the Integrated Personnel and Payroll Information System (IPPIS) helps a lot in removing fraudulent payees from the Government payroll in Nigeria.

\section{E-Commerce Development in Nigeria}

The use of Internet to operate business transactions has gain more impetus in the country and it is practiced widely within the more commercially concentrated states of the nation. A lot of new business ventures also known as "business startups" have been observed springing up within the virtual market place and cyber space where the primary target of each one of them is the over $40 \mathrm{mil}$ lion Internet subscribers in the country; Jumia and Konga were reported as the "Beasts" or the leaders of e-Commerce in Nigeria as both of the business organizations have shown commitment towards the use of e-commerce technology in their business transactions [26]. The series of changes that reflect the growth rate of Internet subscribers in Nigeria from year 2000 to 2010 was examined by [13] in their research. The result of their studies revealed that the total number of In- 
ternet users in Nigeria as at 2000 were 200,000 representing less than $1 \%$ of $\mathrm{Ni}$ geria's national population; precisely $0.1 \%$ of the country's population have access to Internet, this figure rose sharply to over 40 million precisely $43,982,200$ in June 2010 which represent $29.5 \%$ of the country's population. The continuous growth of the number of Internet users in Nigeria from $0.1 \%$ in 2000 to $29.5 \%$ of its population in June 2010 is a strong determinant for Nigeria's engagement in e-commerce. Table 1 below presents the total number of internet subscribers in Nigeria over the past twenty years and according to [13] [31] [32] [33] [34] the total number of internet users in Nigeria rises from 200,000 in the year 2000 to 1.7 million in 2004 which increases to 30.8 million in 2009; it also jumps to 76.4 million in 2014 and stood at over 126 million subscribers as at $31^{\text {st }}$ December 2019 all these figures are shown in Table 1 below.

According to the 2018 report on business to consumer (B2C) e-commerce index by [35] about 151 countries were ranked globally, including 44 African nations by measuring their readiness for online shopping. The index is based on four key indicators: 1) bank or mobile money account penetration; 2) internet usage; 3 ) availability of internet servers and 4) the reliability of postal services.

Out of the 44 African countries, Mauritius occupies the first position being the highest ranked while Nigeria the Africa's largest e-commerce market by number of shoppers and revenue is the second ranked African nation closely followed by South Africa. Table 2 below presents the top ten African countries based on their e-commerce readiness index with their associated global e-commerce ranking.

\subsection{Factors Challenging the Growth of e-Commerce in Nigeria}

There are numerous factors that challenge the growth of e-commerce in Nigeria thereby adversely affecting Nigeria's economic growth; these barriers include:

1) High Cost of Acquiring Relevant ICT Facilities and Skills

Recent research by some scholars has found that the high cost of acquiring the computer systems, ICT equipment, Internet access cost, cost of personnel training, network installation and maintenance cost and the cost of implementing new technologies such as e-commerce site and its security have thwarted the growth of e-commerce in Nigeria's economy. The low level of broadband penetration and lack of Internet access among the rural dwellers in Nigeria as a result

Table 1. Total number of internet users in Nigeria within the distance of five years over the past twenty years from 2000-2019.

\begin{tabular}{ccc}
\hline Year & Number of Internet Users & Source \\
\hline 2000 & 200,000 & {$[13]$} \\
2004 & $1,749,576$ & {$[31]$} \\
2009 & $30,897,614$ & {$[32]$} \\
2014 & $76,492,866$ & {$[33]$} \\
2019 & $126,078,999$ & {$[34]$} \\
\hline
\end{tabular}


Table 2. Top ten African countries ranked by e-commerce readiness index as at December 2018 (Source: [35]).

\begin{tabular}{ccc}
\hline Rank in Africa & Country & Global Rank \\
\hline 1 & Mauritius & 55 \\
2 & Nigeria & 75 \\
3 & South Africa & 77 \\
4 & Tunisia & 79 \\
5 & Morocco & 81 \\
6 & Ghana & 85 \\
7 & Kenya & 89 \\
8 & Uganda & 99 \\
9 & Botswana & 100 \\
10 & Cameroon & 101 \\
\hline
\end{tabular}

of the high cost involved in acquiring such facilities has impeded the growth of e-commerce in Nigeria. Additionally, Internet access is not readily accessible to most users in the developing countries because of its high cost [2] [20] [36].

\section{2) Socio-cultural barriers}

The situation of socio-cultural barriers to e-commerce in the developing countries enunciated by McKinsey op cit [16] holds true in Nigeria that the preference for personal face-to-face communications rather than the electronic versions of communication like e-mails followed by a strong affinity for established physical business relationships instead of the inter-personal Internet enabled business relationship proves to be a strong enemy of the growth and development of e-commerce in the economies of third world countries. [20] opined that it may not be acceptable to deliver physical goods to women when they are alone at home in some parts of the country particularly Northern Nigeria; even if such goods were ordered from an e-commerce online store, the e-commerce delivery agent must have to wait for the presence of another person before such delivery can be made and this factor is believed to have crippled the growth of e-commerce in Nigeria.

\section{3) Security and legal Issues}

The low level of ICT and computer literacy as well as general lack of understanding regarding the operations of the Internet was clearly spelt out by [37] as another factor that exposes consumers in e-commerce to different risks; this factor tends to deter e-consumers from active participation in e-commerce transactions thereby crippling the growth of e-commerce in Nigeria. According to [38] despite the good intentions of the Central Bank of Nigeria by introducing the cash-less economy policy which is aimed at promoting the economic growth of the country through financial inclusion, revenue leakage minimization, reduction in the level of robbery and also reduction in the amount of cash payment in favor of electronic payments. The emergence of security challenges such 
as cybercrime and related electronic fraudulent practices in financial institutions that operates within the country renders the effort of the Central Bank of Nigeria, CBN's cashless transformation project useless. Researches by [16] suggested that the lack of a functional legal framework and proper policies that can address the problems of the validity of electronic transactions in an online business is a strong factor that inhibits the growth of electronic commerce in the economies of the developing countries.

\section{4) Cognitive Barriers}

Recent researches have shown that business owners and enterprises were restricted from making use of the Internet technologies to carry out business transactions in the developing countries due to the way in which their customers behaves by demonstrating a very strong unwillingness to use the Internet for online business transactions and also because of the lack of commitment of the top management in using the technology. Additionally, there is a perceived lack of trust on the part of prospective customers in an e-commerce market space due to fear of cyber-crime; these issues mentioned above constitute the strongest hindrance to the adoption of Business-to-Consumer (B2C) e-commerce in Nigeria today [17] [20].

\section{5) Logistic and Delivery Barriers}

The concept of logistic and delivery in e-commerce involves the transportation and delivery of the ordered goods to their consumers. The authors [39] argued that logistics and courier services needed a lot of improvement in India, owing to the fact that an effective logistic service is ideal for the success of all online retailers. India was reported to be lagging behind in this sector; this problem of lack of effective logistic and delivery services is also peculiar to Nigeria, other problems of logistic and delivery that negatively affect e-commerce in Nigeria are the delay in delivering the products, loss of product during delivery and delivery of products to wrong individuals.

\section{6) Poor electricity supply}

Poor electricity supply is also one of the factors that inhibit the growth of electronic commerce in Nigeria. Previous study by [2] indicated that $97 \%$ of Nigerian firms and business organizations experience power outages of one form or the other. [40] in their research opined that the nature of electricity supply in Nigeria is very epileptic and it proves to be one of the greatest challenges that confronts the Nigeria's business sector; E-marketing, E-commerce or E-business can never be practiced effectively without regular power supply therefore many business set ups were forced out of the E-commerce market place as a result of poor electricity supply.

\subsection{Recommendations}

In order to harness the power of the innovations in ICT and implement an effective, reliable and responsive e-commerce system in Nigeria, this paper wish to recommend the following measures which Nigerian government and business 
organizations should adopt as follows:

1) Nigerian government should in addition to the ICT policy formulations such as the introduction of computer studies in Nigerian education sector introduce e-commerce into the national curriculums. This will discourage the cognitive factor as a barrier that Challenges the Growth of e-commerce in Nigeria and will promote the e-commerce readiness in the country.

2) Nigerian government should ensure that ICT services and electricity supplies are available, accessible and affordable to all Ministries, Departments and Agencies (MDAs), business organizations and her citizens

3) The Federal government of Nigeria through the ministry of communications and digital economy should ensure that secured Internet data connectivity should be made available to Nigerian citizens residing in the urban and rural areas at a lower cost as it stands to address the security challenges affecting the progress of e-commerce in Nigeria.

4) One of the hindrances to the successful implementation of e-commerce project in Nigeria is the low rate of ICT literacy or Skills which can be addressed by embarking on formal and informal ICT training for all Nigerian citizens.

\section{Conclusion}

Today, e-commerce has affected the global economy in numerous ways primarily due to its vast possibility for strengthening economic growth and business expansion worldwide. It can be concluded that both the existing business set ups and start-up entrepreneurs in Nigeria can only be engaged in a healthy business competition with their contemporaries in other countries of the world if they would integrate e-commerce technologies into their business transactions. For a developing country like Nigeria to exploit the benefits of e-commerce in her economy, the factors challenging the growth of e-commerce such as the high cost of acquiring relevant ICT facilities and skills, socio-cultural barriers, security and legal issues etc. discussed in this paper need to be addressed by the Nigerian Government.

\section{Conflicts of Interest}

The author declares no conflicts of interest regarding the publication of this paper.

\section{References}

[1] Gupta, A. (2014) E-Commerce: Role of E-Commerce in Today's Business. International Journal of Computing and Corporate Research, 4, 1-8.

[2] Kuliya, M. (2015) The Impact of Information and Communication Technology in the Growth of E-Commerce in Nigeria: Challenges and Prospects. International Journal of Scientific and Research Publications, 5, 507-512.

[3] Chris, A. (2012) Challenges and Opportunities in the Implementation of Electronic Commerce: The Case of Nigeria. African Journal of Business Management, 6, 11495-11503. https://doi.org/10.5897/AJBM12.1156 
[4] Muhammad, J., Dominic, P.D.D., Naseebullah and Alamgir, K. (2011) Towards Digital Economy: The Development of ICT and E-Commerce in Malaysia. Modern Applied Science, 5, 171-178. https://doi.org/10.5539/mas.v5n2p171

[5] Alain, D. and Jean-Marc, K. (2015) E-Commerce in Africa (Morocco, Tunisia, Senegal and Ivory Coast) Recommendations for Regional Integration in the Mediterranean. Institut De prospective Economique Du Monde Mediterraneen (IPEMED). http://www.ipemed.coop/adminIpemed/media/fich_article/1461745665_ipemed-ra pportecommerce-en-afrique-enbd.pdf

[6] International Trade Centre ITC (2015) International E-Commerce in Africa: The Way Forward.

[7] Muhammad, N., et al. (2017) Critical Analysis of the Legal and Infrastructural Frameworks for E-Commerce and Consumer Protection in Nigeria. The International Journal of Business \& Management, 5, 58-62.

[8] Iluno, E.C. and Yakubu, J.A. (2017) The Impact of e-Commerce on Customer Satisfaction: A Case Study of Kaduna State Metropolis in Nigeria. International Journal of Advanced Studies in Economics and Public Sector Management, 5, 11-19.

[9] Gunasekaran, A., et al. (2002) E-Commerce and Its Impact on Operations Management. International. Journal of Production Economics, 75, 185-197. https://doi.org/10.1016/S0925-5273(01)00191-8

[10] Stephen, A.O. and Ailemen, O.I. (2011) Electronic Commerce, Automation and Online Banking in Nigeria: Challenges and Benefits. Iranian Journal of Management Studies, 4, 29-52.

[11] Mohammad, M.R. (2009) E-Banking in Bangladesh: Some Policy Implications. Bangladesh Bank Quarterly, 6, 1-10.

[12] Morufu, O. and Taibat, A. (2012) Bankers Perceptions of Electronic Banking in Nigeria: A Review of Post Consolidation Experience. Research Journal of Finance and Accounting, 3, 1-12.

[13] Ayo, C.K., Adewoye, J.O. and Oni, A.A. (2011) Business-to-Consumer e-Commerce in Nigeria: Prospects and Challenges. African Journal of Business Management, 5, 5109-5117.

[14] Gabriel, J.M.O., Ogbuigwe, T.D. and Ahiauzu, L.U. (2016) Online Shopping Systems in Nigeria: Evolution, Trend and Prospects. Asian Research Journal of Arts \& Social Sciences, 1, 1-7. https://doi.org/10.9734/ARJASS/2016/29170

[15] Ahmed, L. and Richard, C.O.(2015) E-Commerce, Problems and Prospect in Nigeria. International Journal of Scientific Engineering and Applied Science, 1, 230-236.

[16] Al-Somali, S.A. (2011) Electronic Commerce Adoption: A Study of Business-to-Business Practices in Saudi Arabia. Doctoral Dissertation, Aston University, Birmingham. http://publications.aston.ac.uk/18773/1/Al_Somali_Sabah_A._2011.pdf

[17] Anthony, I., Onwumere, J.U.J. and Obiamaka, P.E. (2014) Examining the Effect of E-Commerce on Business Performance in A Business Environment. Developing Country Studies, 4, 154-159.

[18] https://www.csetutor.com

[19] Gangeshwer, D.K. (2013) E-Commerce or Internet Marketing: A Business Review from Indian Context. International Journal of $u$ - and e-Service, Science and Technology, 6, 187-194. https://doi.org/10.14257/ijunesst.2013.6.6.17

[20] Okoye, H.I. and Obi, C.A. (2015) Development of E-Commerce in Nigeria: The Entrepreneurial Opportunities and Challenges. IOSR Journal of Business and Man- 
agement, 17, 34-39.

[21] Alireza, G., Ebrahim, F. and Lachin, H. (2011) The Study of Information Technology Effect on E-Commerce Growth. 2011 International Conference on Advancements in Information Technology, Singapore, Vol. 20, 50-54.

[22] Yaser, A.N. (2013) An Introduction To Electronic Commerce. International Journal of Scientific \& Technology Research, 2, 190-193.

[23] Okeke, M.N., Oboreh, J.C. and Ezeaghaego, C.C. (2016) Effect of E-Commerce and the Growth of Small Scale Enterprises in Selected Enterprises in Anambra State. Singaporean Journal of Business Economics, and Management Studies, 5, 82-94. https://doi.org/10.12816/0028361

[24] Agwu, M.E. and Murray, J.P. (2014) Drivers and Inhibitors to E-Commerce Adoption among SMEs in Nigeria. Journal of Emerging Trends in Computing and Information Sciences, 5, 192-199.

[25] Tijani, J.A. and Ilugbemi, A.O. (2015) Electronic Payment Channels in the Nigeria Banking Sector and Its Impacts on National Development. Asian Economic and Financial Review, 5, 521-531. https://doi.org/10.18488/journal.aefr/2015.5.3/102.3.521.531

[26] Isa, A.I. and Mohammed, A. (2015) Technological Adoption of e-Commerce in Nigeria. International Journal of Innovative Research in Engineering \& Management, 2, 1-7.

[27] Danish, M.K., Farmeena, K. and Ehmer, M.K. (2014) Growing Importance of E-Commerce in Global Market. Information and Knowledge Management, 4, 48-52.

[28] Edesiri, G.O. and Promise, E.K. (2013) Problems and Prospects of E-Transaction (The Nigerian Perspective). Journal of Research in International Business and Management, 3, 10-16.

[29] Kazeem, O.O. and Kate, D. (2015) Roles of E-Service in Economic Development, Case Study of Nigeria, a Lower-Middle Income Country. International Journal of Managing Information Technology, 7, 13-20.

[30] Javier, E., et al. (2012) The Transformational Use of Information and Communication Technologies in Africa: ICT Competitiveness.

http://www.eTransformAfrica.org

[31] https://www.Internetlivestats.com

[32] https://www.Factfish.com

[33] Nigerian Communications Commission Report. https://www.ncc.gov.ng

[34] https://www.Internetworldstats.com

[35] United Nations Conference on Trade and Development (UNCTAD) (2018) UNCTAD B2C E-Commerce Index 2018-Focus on Africa. https://unctad.org

[36] Japhet, E.L. and Usman, A.T. (2010) Barriers to Ecommerce in Developing Countries. Information, Society and Justice, 3, 23-35.

[37] Lawal, M.M. and Khadija, A. (2012) An Overview of e-Commerce Implementation in Developed and Developing Country; a Case Study of United State and Nigeria. International Journal of Modern Engineering Research, 2, 3068-3080.

[38] Leonard, C.O. (2014) Tax Challenges of E-Commerce in Nigeria: The Panacea for Legal Jurisprudence. Global Journal of Politics and Law Research, 2, 1-5.

[39] Franco, C.E. and Bulomine, R.S. (2016) Advantages and Challenges of E-Commerce 
Customers and Businesses: In Indian Perspective. International Journal of Research-GRANTHAALAYAH, 4, 7-13.

[40] Andrew, A.U. and Erezi, B.U. (2014) Marketing in Nigeria: An Essential Tool for Globalization of Fashion Business in the E-Business World. African Education Indices, 7, 1-9. 